\title{
Convergence to international financial reporting standards: the case of Turkey
}

\section{Can Simga-Mugan*}

Faculty of Economic and Administrative Sciences, Department of Management, Middle East Technical University, Ankara 06531, Turkey

E-mail: mugan@metu.edu.tr

${ }^{*}$ Corresponding author

\section{Nazli Hosal-Akman}

Faculty of Business Administration, Bilkent University, Bilkent, Ankara 06800, Turkey

E-mail: nakman@bilkent.edu.tr

\begin{abstract}
In this paper, we discuss the progress in the accounting standards in Turkey and provide some insight into the current accounting system as well as the recent regulatory developments following the convergence attempts to the global set of financial accounting standards that is currently referred to as the International Financial Reporting Standards/International Accounting Standards (IFRS/IAS) in Turkey. The paper emphasises variations from and similarities with the IFRS/IAS and lays out a brief history of global convergence activities. The paper concludes with a discussion of the effects of convergence on the financial reporting and accounting systems of domestic and multinational companies, and audit firms in Turkey.
\end{abstract}

Keywords: IFRS; IAS; Turkish accounting standards; convergence.

Reference to this paper should be made as follows: Simga-Mugan, C. and Hosal-Akman, N. (2005) 'Convergence to international financial reporting standards: the case of Turkey', Int. J. Accounting, Auditing and Performance Evaluation, Vol. 2, Nos. 1/2, pp.127-139.

Biographical notes: Can Simga-Mugan is Professor in accounting, and her current area of research is related with international accounting standards, convergence, emerging markets, and business ethics.

Nazli Hosal-Akman is Instructor in accounting, and her main area of research is related with international accounting standards, convergence, and accounting education. 


\section{Introduction}

Globalisation of financial markets and the expansion of investment and financing activities increased the importance of international accounting and intensified the focus it deserves as a major area of interest. Before the onset of the global set of standards, accountants faced difficulties in preparing comparable financial statements across nations. The difficulties mainly were in having numerous regional or national set of standards that were in effect in one country or one region, which might or might not have been the same, or at least similar with the standards of another country or region. Ever-increasing international operations such as foreign direct investments, foreign portfolio investments, and extensive use of financial instruments in foreign markets placed a new burden on the accountants to interpret and analyse financial statements prepared in different countries according to various set of rules.

Companies enter global markets with the purpose of increasing their profits and/or sustaining their growth. An earlier report on the US manufacturers in the global marketplace states that companies that are mostly active in Eastern and Central Europe, Latin America, and the Middle East via foreign direct investment achieve higher profits than those operating in Western Europe and North America (Deloitte and Touche Review, 1994). As a developing country, Turkey also receives foreign investment from several developed countries. As of June 30, 2003, there were 6,584 multinational companies in Turkey, of which 2,999 were from the European Union countries and 393 from the USA. ${ }^{1}$ Turkish companies extended their regions of operations and now they own foreign direct investments as well. Between 2000 and 2002, the amount of direct investments of Turkish companies in other countries amounted to over one billion USD. ${ }^{2}$ These investments are mostly in the European countries and in the Newly Independent States formed after the Soviet Union.

In addition to foreign direct investment, there is heavy international portfolio investment as well. Harvey (1995) reports that average returns of the emerging markets are almost $50 \%$ higher than the returns of the developed markets. Even recently as in the second quarter of 2002, US stock market returns reflected a loss of $13.4 \%$ while the emerging stock markets returns had a decrease of $8.4 \%$ only. ${ }^{3}$

In summary, globalisation of commercial and investing activities reinforces the need of a single set of financial reporting. The recent accounting scandals further revealed the need of revising the current accounting standards worldwide. Thus, currently one of the main issues of international accounting is the convergence of accounting standards.

Turkey as a developing country with an emerging capital market is also preparing herself for the developments in financial reporting. This paper presents the current accounting system as well as the recent regulatory developments following the convergence attempts to the global set of financial accounting standards that is currently referred to as the International Accounting Standards/International Financial Reporting Standards (IFRS/IAS) in Turkey.

After brief overview of global convergence activities and related research, a brief history of accounting in Turkey is given. Then, the paper presents the current accounting practices in Turkey while emphasising variations from and similarities with the IFRS/IAS. The paper concludes with a discussion of the effects of convergence on the financial reporting and accounting systems of domestic, multinational enterprises, and audit firms in Turkey, and the expectations of the users of financial information. 


\section{Convergence activities and related research}

Since 1950s, academicians and practitioners searched for rules and practices, which would enable the same interpretation of the financial statements that are produced under different national accounting systems (Chandler, 1992). These efforts led to emergence of two main trends: harmonisation of the accounting standards and convergence of accounting rules. Harmonisation of accounting standards requires that cross-national rules be brought in line with each other or with an international standard setting body regulations. In cases of harmonisation efforts, there is a 'leader' and a 'follower' standard setter(s) who designs the accounting rules in a way that would minimise the differences with the accounting rules of the leader, and permit reconciliation. In the last two decades, International Accounting Standards Committee (IASC) was the international standard setting body that issued International Accounting Standards (IAS) with which national bodies tried to harmonise their own rules.

Related literature is profuse with numerous studies arguing for or against harmonising the accounting standards globally. For example, proponents of harmonisation state that the benefits of harmonisation include elimination of arbitrary assumptions to set financial statements to the same base while arguing harmonisation may not be essential for security investors since they utilise decision criteria independent of accounting manipulations (Goeltz, 1996). From a different perspective, others argue that well-established accounting standards appear to be beneficial to companies attempting international mergers (Black et al., 2004). Another line of argument against harmonisation is the 'accounting colonialism' imposed on developing countries by the developed countries (Chandler, 1992).

Currently, the global trend is convergence of accounting standards in which the ultimate goal is to create a single set of high quality standards. In order to achieve this goal, the 'best' standard among the existing standards is determined, or if such is not possible, a new standard is developed. The standard setting body in this case is the International Accounting Standards Board (IASB) that is formed in place of IASC with greater national and regional support. This support was demonstrated in a recent study, which shows that several nations have already taken steps to converge their regulatory framework with the requirements of the International Financial Reporting Standards (IFRS/IAS) (Street, 2003a).

The impetus behind the acceptance of IFRS/IAS globally is the firm support stated by the Securities Exchange Commission (SEC) and Financial Accounting Standards Board (FASB). The initial cooperation between FASB and IASC started in 1987 when FASB participated in the Executive Committee Meeting of IASC as an observer. Although FASB was mainly interested in the US-based reporting and recording systems, with the expansion of cross-border investments and financing, the need to understand and interpret financial reports prepared according to different set of rules arose. Within this framework, FASB realised the 1st Strategic Plan in 1991 to manage its international activities. As a result of the increased support of FASB to international accounting standards and the mutual effort in some projects with IASC (later IASB), the two standard setting bodies came closer. The collaboration between FASB and IASB enhanced further when IASB's former president was appointed as FASB president recently. 
Recently, Blanco and Osma (2004) investigated the differences between IAS and US GAAP for the non-US companies listed on the US stock markets. Their results show that while the number of adjustments is increasing, their materiality decreases. Thus, the authors conclude that the gap between these two standards is narrowing.

Close relations between IASB and Europe started in 1989, when Federation of European Accountants (FEA) supported the harmonisation activities. The relations were strengthened in 1997 when FEA urged the European listed companies to apply IAS. The European Commission supported the use of IAS by large companies in preparation of the consolidated financial statements within the framework of 4th and 7th Directives in 1995. Finally in 2000, the European Commission stated that all companies listed in the European Stock Exchange Markets should prepare their financial statements in accordance with IFRS starting from 2005.

Convergence activities carried out by different countries involve different steps and procedures. Venezuela, for example, adopted IFRS/IAS without any modification requiring both listed and non-listed companies to apply IFRS/IAS starting from $2006 .{ }^{4}$ On the other hand, all companies in Croatia, including the small and medium sized ones, are required to prepare IAS-based reports since $1992 .{ }^{5}$

Starting in 2005, Swiss listed companies will be required to apply either IFRS/IAS or US GAAP with the exception of non-multinational companies. Such companies will continue to use national standards. ${ }^{6}$ A similar approach was carried out earlier by Germany when in 1998 listed companies were exempted from national standards and permitted to apply either IFRS/IAS or US GAAP. The non-listed German companies continue to apply national standards (Street, 2003b).

As opposed to Germany, French and Italian companies are not permitted to apply IFRS/IAS. Instead national standards are changed to adapt IFRS/IAS. Delvaille et al. (2004) compare the reporting processes in these countries and state that permission by the German legislators in 1998 to prepare consolidated statements according to IAS has led to significant changes in the reporting practices. The authors also state that reporting practice has not changed and although France is prepared for the change, Italians are more "pessimistic about the advantages of the IAS-IFRS/IAS than the other European Companies" (p.15). Raffournier and Dumontier (2004) explore the relationship between the stock market prices and the accounting standards employed. Their findings reflect that earnings computed based on IAS are more closely related with stock prices than local accounting rules in Switzerland, Germany, and Austria. As a matter of fact, these countries are the early adopters of IFRS/IAS (Street, 2003a; 2002).

A recent study analyses accounting policy choices across the European Union countries regarding inventory costing, goodwill, and depreciation (McLeay and Jaafar, 2004). The authors find that country of domicile and sector a firm operates in significantly affect the accounting policy choice. Leuz and Verrechia (2000) examine the relationship between a firm's international reporting strategy and its performance. The authors investigate the association between increased disclosure brought by applying IAS or US GAAP in some German firms and stock market movements. They find share volume volatility around the switching dates, but no price volatility. The reason of this finding could be due to the mechanism developed by the investors to deal with international differences in accounting regulations as suggested in Bhushan and Lessard (1992). 


\section{A brief history of accounting in Turkey}

The development of accounting practices in Turkey is heavily influenced by the practices of a number of Western countries because of the economic and political ties during a specific period. The first Commercial Code of 1850 was a translation of the French Commercial Code, and reflected the French influence of the era. This law formed the first accounting regulation in Turkey (Bilginoglu, 1988). End of the 19th century and the beginning of the 20th century mark the increased trade relations between Turkey and Europe, especially Germany. Until the First World War, most of the 215 businesses in the country were controlled by German and French entrepreneurs (Walstedt, 1980).

The historical and political developments during the First World War, and the fact that Germans operated most of the foreign manufacturing businesses at the emergence of the Republic of Turkey, jointly led to strong German influence on the economic developments in Turkey. Following the establishment of the Turkish Republic in 1923, a second Commercial Code was enacted in 1926. This code was based on the German commerce and company laws that also regulated the accounting practices.

Due to lack of private capital and thus privately owned companies during the early years of the Republic, the state took the responsibility to initiate heavy industry and several manufacturing companies. These state founded and operated companies are called 'State Economic Enterprises' (SEE), and Sumerbank (mine and textile products) was the first one to be founded in 1933. It was originally entrusted with the operation of principal mines that were recently acquired through nationalisation from the German companies. Therefore, it is not surprising to see that Sumerbank's - and other SEEs as well-accounting system was organised by the Germans. One of the objectives of the SEEs was to assist in development of the private sector (Walstedt, 1980). Hence, the German influence was carried to the private sector as well.

Furthermore, in the late 1930s, Turkey welcomed German academicians of various fields in the Turkish universities. Consequently, financial and cost accounting practices of the State Economic Enterprises, and the training by the visiting German professors established the rules for accounting practices in the private companies (Bilginoglu, 1988).

In the first three decades of the Republic, between 1920 and 1950, Turkish economy was a conservative one in which the State initiated the economic activities. After the World War II, the developments in the world economy, such as the Bretton Woods Economic Conference, affected the Turkish economy and politics alike. Establishment of a multi-party era in 1946 led to a limited liberation movement in this decade. In 1950, the Turkish Industrial Development Bank was founded with support from the World Bank to foster and finance private industrial investments. In the early $1950 \mathrm{~s}$, the country enjoyed an economic growth she had never seen before. The economic boom ended in mid-fifties, and followed by a period of economic crisis. A major outcome of the crisis was the need for foreign loans that eventually led to the International Monetary Fund (IMF) imposed stabilisation programme in 1958 (Ceyhun, 1992).

The decade of 1950-1960 marks the first attempts towards a more liberal economy in which international trade gained momentum (Kilicbay, 1991). The current Commercial Code of 1956, which came into effect starting on January 1st, 1957, was in line with the contemporary economic developments as well.

Turkey applied for the European Union membership (formerly EEC-European Economic Community) in 1959, and she is still an applicant country. Therefore, although accounting and audit rules stated in the fourth, seventh, and eighth company directives of 
the EEC have been translated into Turkish and discussed in various circles, no action has been taken to incorporate them in the Turkish regulations.

During the decade of 1950-1960, incentives were provided for the private sector and for foreign investments. Starting from the second half of this decade, US expertise has been utilised and the economic system has been heavily influenced by the US system. Successful individuals in various fields have been trained and have pursued graduate degrees in foreign countries, especially in the USA, beginning in the late 1950s. Upon return of these individuals, the accounting system has been heavily influenced by the US system or Anglo-Saxon system since the beginning of the 1960s. Development of the uniform chart of accounts for the State Economic Enterprises in 1974 reinforced the effect. Furthermore, the US influence was also felt in the curriculum of the business schools, especially in the field of business administration and accounting.

In January 1980, a series of economic decisions imposed by the IMF were taken to reduce the inflation rate, increase production, and support the import activities. During the reconstruction period starting in the early 1980s, law no. 2499 was put into effect in 1981 to prepare the grounds for establishing capital markets. The law of Istanbul Stock Exchange (ISE) came out in 1984, but full operations started in 1986 and it is still the only stock exchange in Turkey. Foundation of the Capital Markets Board (CMB) and the Istanbul stock exchange, and the increase in foreign investments advanced the development of the accounting and auditing standards. Increase in joint ventures and foreign trade led to establishment of offices of the then-'Big Eight' accounting firms in Turkey. As a result of these developments, large private enterprises started to report their financial statements in accordance with the International Accounting Standards in addition to national reporting requirements.

The first set of financial accounting standards for the publicly owned and/or traded companies was developed in January 1989 by the CMB to be in effect for the fiscal years that start on or after January 1st, 1989 (Kurulu, 1989). A revised version of these standards is still in effect and regulates the preparation and presentation of financial statements of the publicly traded companies and listed companies, ${ }^{7}$ insurance companies, banks, and brokerage firms, and they are comparable with the international accounting standards.

As apparent from the above discussion, the environment surrounding the accounting practice in Turkey went through several transformations. However, accounting standards to be used by the family-owned or small to medium sized companies did not show such a development, and accounting was, and to some extent still is, treated as identical with tax accounting.

Moreover, although there have been several attempts to form an accounting body since the 1940s, there was none to pursue the establishment of standards until the second half of the 1980s. The main reason for this delay is the lack of pressure on the Turkish companies to provide publicly available and comparable financial statements because most of the businesses were family owned. The accountants in such companies were responsible for bookkeeping for tax purposes (i.e., follow procedural tax code); cash management; budgeting; preparation of tax returns and financial statements required by the tax codes; and very limited internal auditing.

In 1992, the Ministry of Finance organised a committee to instigate the accounting principles and a uniform chart of accounts that would be used by all companies. The Ministry published the committee's report in a communiqué on December 26, 1992 establishing the principles and the uniform chart of accounts to be in effect starting 
January 1st, 1994 (Bakanligi and Tebiligi, 1992). All companies except banks, brokerage firms, and insurance companies are required to conform to the guidelines stated in the communiqué. Banks are subject to accounting rules set by the Central Bank of Turkey and Banking Regulation and Supervision Agency, and brokerage and insurance firms comply with the CMB rules.

In February 1994, the Turkish Accounting and Auditing Standards Board (TAASB) was formed with the mission to develop accounting and auditing standards. The aim of TAASB was to develop accounting standards in Turkey for consistent preparation and presentation of financial statements. As of January 1st, 2002, TAASB prepared 19 accounting standards under the name of Turkish Accounting Standards (TAS) that were published by TURMOB (Union of Chambers of Certified Public Accountants of Turkey). In practice, however, those standards were not widely applied by the Turkish companies and the Board was dissolved and re-formed as the Turkish Accounting Standards Board (TASB) under the Prime Ministry in April 2002. TASB is in the process of reviewing the existing accounting standards in light of the IFRS/IAS but has not issued any standards yet.

As a result of the above-mentioned developments, financial reporting for different types of companies is regulated presently by the Ministry of Finance's regulation of 1992, the CMB rules, the Commercial Code and the Procedural Tax Law, Banking Regulation and Supervision Agency, and the Central Bank regulations. The Commercial Code and the Procedural Tax Law establish the disclosures required in the financial statements of all profit oriented companies. These companies must also meet requirements in the Ministry of Finance's communiqué of 1992. On the other hand, publicly traded and listed companies and financial intermediaries are regulated by the CMB rules as well.

\section{Current status of the Turkish accounting standards}

The accounting principles and policies stated in the 1992 communique (Bakanligi, 1992) and the CMB regulations (Kurulu, 1989) essentially follow the internationally accepted accounting principles and policies. These include the underlying assumptions such as going concern, consistency, time period, unit of measure, and the basic principles like cost, matching, prudence, objectivity, materiality, substance over form, and full disclosure. According to tax rules, on the other hand, in principal accrual accounting is recognised, but treatment of certain items is closer to cash accounting.

The discussion in the following paragraphs involves a brief comparison of the accounting principles set forth by the current $\mathrm{CMB}$ regulations (CMB rules) and IFRS/IAS. As mentioned earlier, all publicly traded companies should apply the CMB rules, and if they have any international affiliation they usually prepare financial statements in accordance with the International Accounting Standards as well.

Until January 1st, 2003, the fundamental difference between the CMB rules and IFRS/IAS was accounting for inflation and long-term investments. Although Turkey has been experiencing high rates of inflation in the last three decades, there were no regulations that required inflation accounting, except for the annual revaluation of property, plant, and equipment and the use of last-in first-out method of inventory valuation. Furthermore, the long-term investments were carried at cost. In January 2002, the $\mathrm{CMB}$ issued the accounting rules that cover financial reporting under inflationary 
economies together with the consolidation and equity accounting for long-term investments. These principles are similar to those of IFRS/IAS and became effective starting January 1, 2003. The Ministry of Finance also issued a regulation for inflation adjustment in December 2003 to be effective from January 1, 2004, it and accepts the adjusted figures for tax purposes. ${ }^{6}$ The procedures stated in both regulations are essentially the same with some computational differences in fixed assets adjustments due to the application of revaluation procedures for fixed assets allowed by the Ministry of Finance.

Presently, there are some major issues that are covered in IFRS/IAS but not in the current CMB rules. The issues can be summarised as follows: ${ }^{8}$

- impairment of assets (IAS 36)

- the de-recognition of financial assets (IAS 39)

- provision for employee benefits other than lump sum termination indemnities (IAS 19)

- $\quad$ segment reporting (IAS 14)

- provisions, contingent liabilities and contingent assets (IAS 37)

- deferred taxes (IAS 12)

- treasury shares (IAS 32)

- hedge accounting (IAS 39).

Furthermore, there are certain differences between the current CMB rules and IFRS/IAS that could lead to reporting of different financial results and financial position. Major differences are presented below.

\subsection{Measurement issues}

- according to the CMB rules, foreign exchange losses that arise from acquisition of property, plant, and equipment can be capitalised after related asset is put into use. IFRS/IAS, on the other hand, requires recording of such foreign exchange losses as period expenses

- the $\mathrm{CMB}$ rules require that construction contracts should be accounted for using the completion of contract method whereas IFRS/IAS requires the use of percentage of completion or cost recovery methods

- although IFRS/IAS treat organisation and research costs as period expenses while permitting capitalisation of development costs under special circumstances, CMB rules allow for capitalisation of organisation, research and development costs

- amortisation period of goodwill is different between the two sets of standards

- while IFRS/IAS requires discounting of the pension obligations to present value, CMB rules do not impose such a requirement

- all types of leases are accounted for as operating leases according to the CMB rules. 


\subsection{Disclosure issues}

- According to the CMB rules, the scope of related parties is limited to shareholders, subsidiary, and equity investments whereas related parties are more broadly defined in IFRS/IAS.

- There are no specific disclosure requirements relating to the fair value of financial assets and liabilities except for marketable securities under the CMB rules.

- Statement of Changes in Shareholders' Equity is not required by the CMB rules.

- Format of the statement of cash flows does not require breakdown of cash flows according to the type of activity according to the CMB rules.

The immediate effect of global developments on the Turkish accounting systems manifested itself in the instigation of the new set of CMB accounting rules that are essentially the same as the International Financial Reporting Standards. On November 17, 2003 the CMB published the Accounting Standards in the Capital Market, ${ }^{9}$ which will be in effect starting from January 1st, 2005 with an option for early adoption. Although all traded and listed companies are expected to comply with these standards, no specific measures have been taken for the reporting of non-listed companies or small and medium sized enterprises (SMEs). Unless they enter into international partnership or have international investors, such companies will continue to follow the Ministry of Finance's 1992 communique and other regulations imposed by the Ministry such as the inflation accounting and thus mainly follow tax-based accounting (Bakanligi and Tebiligi, 1992). As of the end of October 2004, TASB has been designated as the official translator of IFRS by IASB. The Board plans to complete the translations by the end of 2004. At the same time, Turkish Commercial Code is going under revision to require companies to keep their records according to Turkish Accounting Standards. When this law is enacted, all companies will be affected by the convergence activities.

\section{Effects of convergence in Turkey}

We would like to discuss the possible effects of convergence in Turkey from two different perspectives: effect on different kinds of companies and effect on the users of financial information.

\subsection{Companies}

As it stands, the new set of CMB rules only governs the reporting of companies whose stocks are listed and traded at ISE. Listed multinational companies that already prepare their financial statements in accordance with both the CMB rules and IFRS/IAS will be relieved from the burden of reporting under different set of accounting rules. Another benefit of convergence will materialise in their consolidation practices. Using the same set of rules globally will help them produce their consolidated financial statements of the subsidiaries in various countries more efficiently and effectively. 
Listed domestic companies will face the main and immediate difficulty that may arise after the convergence. Most of such companies are not familiar with the content of the new CMB rules. Especially we can expect that pension liability accounting, deferred taxation, and accounting for derivatives and intangible assets to pose several difficulties while companies prepare their financial statements because such issues are not covered in the existing $\mathrm{CMB}$ rules. One major anticipated benefit of convergence for the domestic companies will emerge when such companies engage in international operations such as joint ventures, foreign direct investments, or cross-listing in the European capital markets.

As discussed earlier in the international accounting circles, the benefit of convergence is expected to manifest itself for the cross-listed companies (Raffournier and Dumontier, 2004). Ukraine provides a good example for the argument that international accounting standards would create problems in countries where accounting is regulated on legislative basis. The study (Golov and Kostyuchenko, 2004) states several differences related to consolidation in Ukraine with the IFRS/IAS.

However, both multinational and domestic listed companies will continue to prepare two sets of financial statements: one for financial reporting and one for tax purposes. At a recent panel discussion, ${ }^{10}$ the Chief Financial Officer of a listed company in Turkey indicated her initial concerns for the converged accounting standards as the increased need of consulting, increased audit costs, and the significant differences in net income reported for taxation purposes that also raises the issue of profit appropriation. McLeay and Jaafar (2004) determine the factors that affect choice of accounting policies as the home base of country, size of the industry the firm operates, and international listing.

The new CMB rules do not cover the recording and reporting regulations of all the companies that are subject to CMB regulations. The privately held companies whose stocks are not traded in the stock exchange but their shareholding structure requires them to report to $\mathrm{CMB}$ and apply $\mathrm{CMB}$ rules, will continue to prepare their financial statements in accordance with the current $\mathrm{CMB}$ rules, and such rules have significant differences with IFRS as explained in the previous paragraphs.

\subsection{Users of financial information}

The convergence of accounting standards in Turkey will affect many parties covering both the internal and external users of financial statements. For external users such as foreign and domestic stock investors, the convergence will definitely bring transparency and comparability. These users will find themselves at ease while making investment decisions by the help of comparable and consistent financial data. Convergence of the CMB rules with IFRS/IAS will especially benefit the domestic investors who are current or potential investors in international capital markets since they will be using the financial statements prepared according to the same set of standards in their investment decisions. On the other hand, domestic investors who invest in the ISE only will benefit from increased transparency and additional disclosure. If we assume that increased transparency and information content of financial statements would attract new investors, then we could expect the trading volume in the ISE to increase following the adoption of the new standards. However, this expectation needs to be verified with future empirical research. 
The proposed changes in disclosure and particularly in measurement issues stated above will bring additional responsibilities to auditing firms, which are expected to be knowledgeable on the new set of accounting rules. Apparently, finance executives and accounting departments will need extensive training on the application of the new $\mathrm{CMB}$ rules. Such training will require the mutual efforts of academicians, regulators, and the auditing firms. As two recent studies indicate, chief executive officers who were interviewed explicitly stated the urgent need for comprehensive training and simplification of the international accounting rules before the enforcement of IFRS/IAS in the European Union countries in 2005 (PriceWaterhouseCoopers, 2002). We believe that the Big-Four accounting firms in Turkey actively participated in the issuance process of the new set of standards by reviewing and commenting on the exposure draft. We also believe that they are currently working on to how to provide comprehensive consulting and training services to the companies that do not have sufficient workable knowledge of the standards. The fact that these auditing companies would be the most knowledgeable parties about the new rules would bring additional ethical concern. In other words, the employees who could provide training and consulting would most probably be the ones who would carry out the audit procedures as well. Thus, the regulators should be very careful in monitoring the audit and consulting works.

\section{Conclusion}

International activities expanded notably in the last three decades. For many companies, these activities consist of trading activities, and on a larger scale, these expansions reflect investment in foreign firms or establishing foreign subsidiaries. Consequently, there has been an increasing demand for information from financial statements prepared internationally.

As a developing country with an increasing number of foreign direct investments and with an emerging stock market, the Turkish accounting practice has evolved considerably since the establishment of the Republic. The main changes were initiated by the Government, i.e., Ministry of Finance, or government controlled institutions, i.e., Capital Markets Board. In 2003 the CMB revised the accounting standards for the publicly traded companies. The aim of the revised standards is to converge the Turkish accounting standards to IFRS/IAS.

In this paper, we summarised the accounting standard developments in Turkey and provided some insight into the changes in the accounting standards and their effects on the users and prepares of financial statements. In the follow-up studies, we plan to carry out two empirical studies on the assessment of preparedness of the companies, and later an extension to determine the effect of revised standards on the market indicators of the ISE.

\section{References}

Bakanligi, M.V.G. (1992) 'Muhasebe sistemi uygulama genel tebligi', Resmi Gazete, 26 Aralik 1992, Ministry of Finance and Customs, 'General Regulations Controlling the Application of the Accounting System', The Official Gazette, 26th December.

Bhushan, R. and Lessard, D.R. (1992) 'Coping with international accounting diversity: fund managers' views on disclosure, reconciliation and harmonisation', Journal of Financial Management and Accounting, Vol. 4, No. 2, pp.149-164. 
Bilginoglu, F. (1988) Muhasebe Organizasyonu (Accounting Organisation), Istanbul Universitesi Muhasebe Enstitusu Yayin No. 54, (Istanbul University, Institute of Accounting Publication No. 54), Istanbul.

Black, E., Carnes, T., Jandik, T. and Henderson, C. (2004) International Accounting Diversity and The Long-Term Success of Cross-Border Mergers, European Accounting Association, Annual Meeting, Prague, April, pp.1-3.

Blanco, J.L.U. and Osma, B.G. (2004) 'The comparability of international accounting standards and US GAAP: an empirical study of Form 20-F reconciliations', International Journal of Accounting, Auditing and Performance Evaluation, Vol. 1, No. 1, pp.5-36.

Ceyhun, F. (1992) 'Turkey's debt crises in historical perspectives: a critical analysis', METU Studies in Development, Vol. 19, No.1, pp.9-49.

Chandler, R.A. (1992) 'The international harmonisation of accounting: in search of influence', The International Journal of Accounting, Vol. 27, pp.222-233.

Deloitte and Touche Review (1994) April 18.

Delvaille, P., Ebbers, G. and Saccon, C. (2004) European Convergence to IFRS: Evidence from Three Continental European Countries in the Preparation for 2005, European Accounting Association, Annual Meeting, Prague, April, pp.1-3.

Goeltz, R.K. (1996) 'International accounting harmonisation: the impossible (and unnecessary) dream?', in Blake, J. and Hossain, M. (Eds.): Readings in International Accounting, Thompson Business Press, London, UK, pp.31-35.

Golov, S. and Kostyuchenko, V. (2004) Consolidated Financial Statements in Ukraine: The Requirement of Time, European Accounting Association, Annual Meeting, Prague, April, pp.1-3.

Harvey, C.R. (1995) 'Predictable risk and returns in emerging markets', The Review of Financial Studies, Vol. 8, No. 3, pp.773-816.

Kilicbay, A. (1991) Turk Ekonomisi (Turkish Economy), Turkiye Is Bankasi Kultur Yayinlari (Turkish IS Bank Cultural Publications), Ankara, No. 263.

Kurulu, S.P. (1989) 'Muhasebe Standartlari', Resmi Gazete, 29 Ocak 1989, Capital Markets Board, 'Accounting Standards', The Official Gazette, 29th January.

Leuz, C. and Verrechia, R. (2000) 'The economic consequences of increased disclosure', Journal of Accounting Research, Supplement, Vol. 38, No. 3, pp.91-124.

McLeay, S. and Jaafar, A. (2004) Accounting Harmonisation in Europe: Country Effects and Sector Effects, European Accounting Association, Annual Meeting, Prague, April, pp.1-3.

PriceWaterhouseCoopers (2002) PricewaterhouseCoopers 2005-Ready or Not, www.pwcglobal.com/ias.

Raffournier, B. and Dumontier, P. (2004) Are IAS More Value-Relevant than European National GAAPs?, European Accounting Association, Annual Meeting, Prague, April, pp.1-3.

Street, D.L (2003a) GAAP Convergence 2002, published by BDO, Deloitte Touche Tohmatsu, Ernst and Young, Grant Thorton, KPMG, PriceWaterhouse Coopers, February.

Street, D.L. (2002) 'GAAP 2001: benchmarking national accounting standards against IAS', Journal of International Accounting, Auditing, and Taxation, Vol. 11, No. 1, pp.77-90.

Street, D.L. (2003b) 'Compliance with disclosure requirements at Germany's new market: IAS vs. US GAAP, with Martin Glaum', Journal of International Financial Management and Accounting, Vol. 4, No. 1, pp.64-100.

Walstedt, B. (1980) State Economic Enterprises in a Mixed Economy, the Turkish Case, World Bank Publication, pp.61-73. 


\section{Notes}

${ }^{1} \mathrm{http}: / /$ www.hazine.gov.tr/english/ybs/ulkeing.htm.

${ }^{2}$ Country fact sheet: Turkey; world investment report; http://www.unctad.org/wir.

${ }^{3} \mathrm{http}: / /$ www.hewittinvest.com/pdf/070102cme.pdf.

${ }^{4} \mathrm{http}: / /$ www.iasplus.com.

${ }^{5}$ Report on the observation of standards and code-Croatia, http://www.worldbank.org/ifa.

${ }^{6}$ www.gelirler.gov.tr.

${ }^{7}$ Companies that have more than 100 shareholders are defined as 'listed companies' and are required to apply the accounting standards published by the CMB.

${ }^{8}$ www.ifad.net.

${ }^{9}$ www.spk.gov.tr.

${ }^{10}$ Harmonisation of international financial reporting standards: how and when, October 3, 2003, Bilkent University. 